\title{
Türkiye Muhasebe Standartları Çerçevesinde Finansal Varlıkların Muhasebeleştirilmesi
}

Hakk1 FINDIK *

\section{$\ddot{O Z Z E T}$}

Finansal piyasaların gelişmesi finansal araçlarda çeşitlilik oluşturmuştur. Muhasebe uygulamaları ve finansal raporlamada uluslararası entegrasyonu sağlama amacında olan uluslararası muhasebe/finansal raporlama standartları da finansal araçlara ilişkin standartlarda karmaşık bir içeriğe sahiptir. 2015 yılı itibariyle zorunlu olarak uygulamaya girmesi planlanan ancak 2018 yllına ertelenen TFRS 9 projesi ile bu karmaşıklığın ortadan kalkması amaçlanmaktadır. Bu çalışmanın amacı başta TFRS 9 olmak üzere finansal araçlar standartları kapsamında finansal varlıklarda sınıflandırma, ölçme-muhasebeleştirme, değer düşüklüğ̈̈, sunum ve açıklama bilgilerine ilişkin ilke ve esaslart ele almak, muhasebe uygulamaları ile çözümlemektir. Finansal borçlar ve türev ürünler çalışmanın kapsamı dışındadır.

Anahtar Kelimeler: Finansal varlık, itfa edilmiş maliyet, değer düşüklüğü, TFRS 9.

JEL Siniflandirmasi: M41, G23.

The Recognition Principles In Financial Assets Within The Scope Of Accounting Standards

\section{ABSTRACT}

The development of financial markets created variety in financial instruments. The international accounting / financial reports standards which aim at providing international integration in accounting applications and financial reporting have a complex content in the standards concerning financial instruments. With the TFRS 9 project which was planned to put into practice as far 2015 but postponed to 2018, it is intended to eliminate this complexity. The purpose of this study is to handle the principles and basics abuout classification, measurement recognition, impairment, presentatiton and explanation information in financial assets in the scope of financial instruments standards especially TFRS 9, and solve them with accounting applications. Financial debts and derivative products are out of the scope of this study.

Keywords: Financial assets, amortised cost, impairment, TFRS 9.

Jel Classification: M41, G23.

\footnotetext{
* Yrd. Doç. Dr. Hakkı FINDIK, Kırklareli Üniversitesi, İktisadi ve İdari Bilimler Fakültesi, İşletme Bölümü, h.findik1881@hotmail.com.
} 


\section{GíRiş}

İşletme bilançolarında finansal araçların değeri göreceli olarak artmaktadır. Finansal araçların çoğunun menkul kıymetlerden oluşması bu araçların piyasa fiyat hareketlerinin sık sık değişiklik göstermesi, türev ürünlerin de bu kapsamda ele alınması finansal araçlarda sınıflandırma, ölçme-değerleme, muhasebeleştirme ve sunum gibi esasları önemli hale getirmiş̧ir. Finansal araçlar; likidite yönetimi, kaynak sağlama, spekülatif kar elde etme gibi avantajları sağladığı gibi, fiyat hareketlerindeki olumsuz değişiklikler ve finansal riskleri barındırması gibi etkileri nedeniyle işletmeye finansal sorunlar da oluşturmaktadır (Kaval, 2008: 469).

Uluslararası Muhasebe Standartları Kurulu (IASB), TMS 39 Finansal Araçlar: Muhasebeleştirme ve Ölçme Standardının yerini alacak TFRS 9 Finansal Araçlar Standardını üç aşamada gerçekleştirmek üzere bir projeyi 2005 yılında başlatmışır. TFRS 9'un 2009 ve 2010 versiyonları yayımlanmış ve isteğe bağlı olarak uygulanmasına izin verilmiştir. Zorunlu olarak uygulamanın 01.01.2015 tarihi ile başlanmasına karar verilmiştir. Ancak, IASB almış olduğu kararla standardın uygulamasını değer düşüklüğü ve finansal riskten korunma muhasebesi kısımlarını da kapsayacak bir bütünlük sağlaması amacıyla 2018 yılına kadar ertelemiştir. Kamu Gözetim Muhasebe ve Denetim Standartları Kurumu (KGK) da uluslararası uyumun sağlanması amacıyla 07.04.2015 tarihli Resmi Gazete'de yayınlanan tebliğ ile TFRS 9'un yürürlük tarihini 01.01.2018 tarihi ve sonrasında başlayan hesap dönemleri olarak belirlemiştir.

TFRS 9'un amacı, finansal bilgi kullanıcılarının finansal varlık ve finansal borçlara ilişkin işletmenin gelecekteki nakit akışlarının zaman, tutar ve belirsizliklerini değerlemelerini öngören ihtiyaca uygun ve faydalı bilgiyi sağlayan finansal raporlama ilkelerini belirlemektir (TFRS 9, m. 1). "TMS 39 Finansal Araçlar: Muhasebeleştirme ve Ölçme" standardı kapsamındaki kalemlerin tamamına TFRS 9 hükümleri uygulanacaktır. TFRS 9 finansal varlıkların ve finansal borçların ölçümü ve muhasebeleştirme esaslarını açıklamaktadır. Bu çalışmada, IFRS 9'un 2014 versiyonu dikkate alınarak finansal varlıklarda sinıflandırma, ölçme ve muhasebeleştirme, değer düşüklüğü, sunum ve açıklama esasları incelenmiştir. Çalışmanın amacına zemin oluşturması açısından finansal araçları düzenleyen muhasebe standartlarının tarihsel gelişimi hakkında bilgi vermek yerinde olacaktır.

\section{FINANSAL ARAÇLARI DÜZENLEYEN MUHASEBE STANDARTLARININ TARIIHSEL GELIŞİII}

Finansal araçlara ilişkin standartların gelişim süreci yaklaşık olarak 20 yılın üzerinde bir geçmişe sahiptir. Bu standartlar üzerinde dünyada halen tartışmalar sürmektedir. $\mathrm{Bu}$ tartı̧̧aların temel konusunu, finansal araçların finansal tablolarda sunum ve değerlemesi oluşturmaktadır (Mısırlıoğlu, 2008: 80). 
1988 yılında Uluslararas1 Muhasebe Standartlar1 Komitesi (IASC), "IAS 32 Finansal Araçlar: Sunum” Standardını, finansal araçlar konusunda çalışmaya başlamıştır. 1995 yılında IAS 32 yayınlanmıştır. 1999 yılında da IAS 39, IASC tarafından yayınlanmıştır. IASC, 2000 yılında Uluslararası Muhasebe Standartları Komitesine (IASB) dönüştürülmüştür. Temmuz 2004 'te IFRS 7'nin ilk taslak hali oluşturulmuş ve 2005 yılında IFRS 7 yayınlanmıştır. IFRS 7 ile daha önce IAS 32'de yer alan finansal araçların finansal raporlarda açılanmasına ilişkin bazı yenilikler getirilmiştir. IFRS 7 yürürlüğe girdiğinde IAS 32'de yer alan açıklamaları yürürlükten kaldırmıştır. "IAS 32 Finansal Araçlar: Sunum” olarak yeniden adlandırılmıştır.

IAS 39'a getirilen eleştiriler, IASB'yi yeni bir proje olarak "IFRS 9 Finansal Araçlar" Standardının yayınlanmasına yöneltmiş ve 12.11.2009 tarihinde IFRS 9 yayınlanmıştır. IFRS 9'da yapılan çalışmalar 2010 ve 2011 yıllarında yoğun bir şekilde devam etmiştir. Öncelikle finansal varlıklarda sınıflandırma ve ölçme konularına yer verilmiştir. IASB'nin yayınladığ IFRS 9'un 2014 versiyonunda değer düşüklüğü ile ilgili önemli değişiklikler yapılmıştır. Daha önce "sinıflandırma ve ölçme" ile başlayan IFRS 9 projesi, 2014 yılında açıklanan versiyonla finansal araçlarda değer düşüklüğü ve finansal risklerden korunma muhasebesi ile ilgili önemli yenilikler getirmiştir.

Bugün itibariyle dört adet finansal araçlar standardı mevcuttur. TMS 32 ile TFRS 7 sunum ve açıklamalara ilişkin bilgiler sunarken, TMS 39 ve TFRS 9 muhasebeleştirme ve ölçmeye ilişkin bilgiler vermektedir.

Çalışmanın amacı doğrultusunda bundan sonraki kısımlarda finansal varlık üzerinde durulacaktır. $\mathrm{Bu}$ bağlamda finansal varlık kavramı, finansal varlıkların sınıflandırılması, ölçüm esasları ve muhasebeleştirilmesi ve değer düşüklüğü konuları açıklanacaktır.

\section{FINANSAL VARLIK KAVRAMI VE FINANSAL VARLIKLARIN SINIFLANDIRILMASI}

Finansal araç, bir işletmenin finansal varlığı iken diğer bir işletmede finansal borç ya da özkaynağa dayalı olarak artışa neden olan herhangi bir sözleşmedir (TMS 32, m. 11). Finansal araçlar finansal varlık ve finansal borç olarak ikiye ayrılmaktadır.

\subsection{Finansal Varlık Kavramı ve Kapsamı}

Finansal varlık; nakit, başka bir işletmenin özkaynağına dayalı finansal araç, işletmenin gelecekteki finansal varlık veya borçlarının takas edilmesi için düzenlenen sözleşmeden doğan hakkı, işletmenin özkaynağına dayalı finansal aracı ile ödeye(bile)ceği olan almak zorunda olduğu türev olmayan sözleşme ile satın alma ve takas dişındaki şekillerde ödeye(bile)ceği türev bir sözleşmedir.

Banka mevduatı işletme için bir finansal varlıktır, banka için finansal borçtur. Ticari alacaklar işletme için finansal varlık iken, diğer işletme için finansal borçtur (Misırlıoğlu, 2008: 68). Nakit, çek, hisse senetleri, özel kesim/kamu kesimi tahvil, senet ve bonoları, finansman bonosu ve hazine bonosu elde eden işletme açısından finansal varlıktır. 
Sermaye Piyasası Kanunu'nun (SPK) üçüncü maddesinde menkul kıymet; ortaklık veya alacaklılık hakkı sağlayan, belli bir meblağı temsil eden, yatırım aracı olarak kullanılan, dönemsel gelir getiren, misli nitelikte, seri halinde çıkarılan, ibareleri aynı olan ve şartları SPK'nca belirlenen kıymetli evrak olarak tanımlanmıştır.

Finansal kiralama işlemi, finansal araç kapsamındadır. Ancak, faaliyet kiralaması bir finansal araç olarak kabul edilmez. Finansal kiralama işlemlerine ilişkin "TMS 17 Kiralama İşlemleri” Standardı bulunmaktadır (TMS 32, UR 9).

Stoklar, maddi duran varlıklar gibi maddi varlıklar, maddi olmayan varlıklar ve kiralama konusu varlıklar finansal varlık kapsamında değildir (TMS 32, UR 10). Bu varlıklara ilişkin TMS/TFRS'de ayrı ayrı standartlar mevcuttur.

Peşin ödenmiş giderler bir finansal varlık değildir. Ertelenmiş gelir ve teminat yükümlülükleri de finansal borç olarak kabul edilmez.

Sözleşmeye bağlı olmayan varlık ve yükümlülük de finansal varlık ya da finansal yükümlülük olarak sınıflandırılmaz. Bu kapsamda gelir vergilerine ilişkin muhasebe işlemleri için TMS 12, karşılık, koşullu varlık ve koşullu borçlar için de TMS 37 standardına göre muhasebeleștirme yapılır (TMS 32, UR 12).

\subsection{Finansal Varlıkların Sınıflandırılması}

Finansal araçlarla ilgili TMS/TFRS'nin öngördüğü sınıflandırmaya göre vergi düzenlemeleri ve Tekdüzen Hesap Planı uygulamaları göz önünde tutulduğunda farklılıklar oluşmaktadır. Finansal araçlar standardı dikkate alındığında, standartların hesap numaralarını ya da hesap isimlerini temel alan bir tanımlama yaklaşımı bulunmamakla birlikte, standartların içeriği ve açılamaları incelendiğinde hesap numaraları ya da hesap isimlerine uygun tanımlama yapabilmek de mümkündür (Demir, 2008: 99-100).

TMS 32 standardı finansal araçların varlık, borç veya özkaynak olarak sunulmaları ile finansal varlık ve borçların netleştirilmelerine ait ilkeleri belirlemiştir. Buna göre; ihraç eden açısından finansal araçlar; finansal varlık, finansal borç ve özkaynağa dayalı finansal araç olarak sınıflandırılacaktır. Finansal araca ait faiz temettü, kayıp/kazançların sınıflandırılması ve finansal varlık ile finansal borçların netleştirilmeleri gereken durumlarda TMS 32 uygulanmaktadır (TMS 32, m. 2). Finansal olmayan kalemlerin alım satımına ilişkin sözleşmeler finansal araç kapsamında değildir (TMS 32, UR 20).

TMS 39'un karmaşık bir içeriğe sahip olması çeşitli eleştirileri de peşinde getirmiştir. Muhasebe standartlarının uygun ve anlamlı muhasebe bilgilerini içermesi istenirken, TMS 39'da aynı tür işlemler için alternatif uygulama olanakları verilmesi bu işlemlerden farklı bilgi üretilmesine sebep olmuştur. Bu standardın uygulanması maliyet/fayda analizi kapsamında değerlendirildiğinde elde edilecek fayda, katlanılan maliyetleri aşmamalıdır. Standardın sağlam bir kuramsal temele sahip olması yeterli olmayıp, uygulanabilir olması da istenmektedir. Aşırı geniş biçimde yazılması anlaşılabilir ve tutarlı uygulamayı sağlayacak kesinliğe zarar vermektedir. TMS 39'un çok fazla alternatif uygulamaya izin vermesi karşılaştırılabilirliği de zedelemektedir. Muhasebe standartlarının en gelişmiş mali piyasalar 
için üretilmesi, gelişmekte olan piyasalarda uygulanabilirliğini sıkıntıya sokmaktadır (Haftacı ve Pehlivanl1, 2007: 147-148). Muhasebe standartlarının temelinde yer alan "ilke bazlı" yaklaşım TMS 39'a "kural bazlı" olarak yansımış olup; finansal araçlarda sınıflandırma, ölçme ve uygulama işlemlerinde bazı güçlüklerin doğmasına neden olmuştur. IFRS 9 ile "ilke bazlı" bir yaklaşım sergilenmeye çalışılmaktadır. İşletme yönetim modeli ve ilgili varlıkların sözleşmesine ilişkin nakit akış özelliklerine dayanılarak sınıflandırma yapılması gerektiği vurgulanmıştır.

Tablo 1: TMS 39’a Göre Finansal Varlıklarda Sunum ve Değerleme

\begin{tabular}{|c|c|c|c|}
\hline Finansal Aracın Cinsi & İlk Muhasebeleştirme & Dönem Sonunda & $\begin{array}{l}\text { Finansal Tablo Dışı } \\
\text { Bırakılmasında }\end{array}$ \\
\hline $\begin{array}{l}\text { Alım Satım Amaçlı } \\
\text { Finansal Varlıklar }\end{array}$ & $\begin{array}{l}\text { Gerçeğe Uygun Değer } \\
\text { (G.U.D.) olarak piyasa } \\
\text { alış fiyatı. G.U.D.'e işlem } \\
\text { maliyetleri dahil edilmez. }\end{array}$ & $\begin{array}{l}\text { G.U.D. ile değerleme } \\
\text { fark1 Gelir Tablosunda } \\
\text { raporlanır. }\end{array}$ & $\begin{array}{l}\text { Satış karı/zararı Gelir } \\
\text { Tablosunda raporlanır. }\end{array}$ \\
\hline $\begin{array}{lr}\text { Vadeye } & \text { Kadar } \quad \text { Elde } \\
\text { Tutulacak } & \text { Finansal } \\
\text { Varliklar } & \end{array}$ & $\begin{array}{l}\text { G.U.D. olarak piyasa alış } \\
\text { fiyatı. G.U.D.'e işlem } \\
\text { maliyetleri dahil edilir. }\end{array}$ & $\begin{array}{lr}\text { Etkin faiz } & \text { oranı } \\
\text { kullanılarak } & \text { itfa } \text { edilmiş } \\
\text { maliyeti } & \text { üzerinden } \\
\text { raporlanır. } & \text { Kar/Zararlar } \\
\text { Gelir } & \text { Tablosunda } \\
\text { raporlanır. } & \end{array}$ & $\begin{array}{l}\text { G.U.D. ile değerlenerek } \\
\text { oluşan fark özkaynak } \\
\text { veya gelir tablosuna } \\
\text { aktarılır. }\end{array}$ \\
\hline $\begin{array}{l}\text { Satılmaya Hazır Finansal } \\
\text { Varlıklar }\end{array}$ & $\begin{array}{l}\text { G.U.D. olarak piyasa alış } \\
\text { fiyatı. Doğrudan ilişkili } \\
\text { işlem } \quad \text { maliyetleri } \\
\text { G.U.D.'e ilave edilir. }\end{array}$ & $\begin{array}{l}\text { G.U.D.'i tespit edilebilen } \\
\text { finansal varlıklar G.U.D. } \\
\text { ile, tespit edilemeyenler } \\
\text { maliyet değeri ile } \\
\text { değerlenir. Değerleme } \\
\text { farkları özkaynak } \\
\text { hesaplarında } \\
\text { muhasebeleştirilir ve } \\
\text { "Diğer Kapsamlı } \\
\text { Gelir"de raporlanır. }\end{array}$ & $\begin{array}{l}\text { Elden çıkarmada oluşan } \\
\text { farklar gelir tablosunda } \\
\text { raporlanır. Ancak G.U.D. } \\
\text { farkları gelir tablosunda } \\
\text { raporlanır. }\end{array}$ \\
\hline
\end{tabular}

Kaynak: İşseveroğlu (2014: 92)

IASB, finansal araçların muhasebeleştirilme ve ölçüm esaslarına ilişkin olarak karmaşık olduğu için eleştirilen TMS 39'un yerini alacak olan TFRS 9'un 2014 versiyonuna göre finansal varlıklar;

İtfa Edilmiş Maliyeti Üzerinden Ölçülen Finansal Varlıklar: Finansal varlıkla ilgili sözleşmeye ilişkin nakit akışlarını tahsil etmek için işletme yönetim modeli

\footnotetext{
${ }^{1}$ Muhasebe Sistemi Uygulama Genel Tebliği’ne göre sonuç hesaplarını gösteren, döneme ilişkin gelir ve giderlerinin yer aldığı temel mali tablolardan olan "Gelir Tablosu", muhasebe standartlarında "Kar veya Zarar Tablosu ve Diğer Kapsamlı Gelir Tablosu" olarak adlandırılmaktadır. Gelir ve giderlerin yer aldığı bölüm "Kar veya Zarar Tablosu" iken, özkaynağa dayalı artış ve azalışların takip edildiği bölüm ise "Diğer Kapsamlı Gelir Tablosu" dur.
} 
kapsamında elde tutulan ve sözleşme koşulları içerisinde belirli tarihlerde anapara ve faiz ödemelerini içeren nakit akışları olan finansal varlıklar bu başlık altında sınıflandırılır.

Gerçeğe Uygun Değer Farkı Diğer Kapsamlı Gelire Yansıtılarak Ölçülen

Finansal Varlıklar: Finansal varlığa ilişkin sözleşmede yer alan nakit akışlarının tahsil edilmesi ile finansal varlı̆̆ı satışını kapsayan bir yönetim modelinde elde tutulan ve sözleşme koşulları çerçevesinde anapara ve faiz ödemelerini içeren nakit akışları olan finansal varlıklar bu sinıflandırma içerisinde yer almaktadır.

Gerçeğe Uygun Değer Farkı Kar veya Zarara Yansıtılarak Ölçülen Finansal Varlıklar: Bir finansal varlık "itfa edilmiş maliyeti üzerinden" ve "G.U.D. farkı diğer kapsamlı gelire yansitılarak ölçülen" finansal varlık kapsamına girmediği takdirde bu sinıflandırma içerisinde yer alır.

TFRS 9'un 2011 versiyonunda yer alan sinıflandırmada "G.U.D. farkı diğer kapsamlı gelire yansıtılarak ölçülen finansal varlıklar" sınıflandırma içerisinde yer almamakta olup, özkaynağa dayalı finansal araçlara ilişkin değerleme farklarının diğer kapsamlı gelirde gösterilmesi gerektiği standart metninde yer almaktaydı. IFRS 9'un 2014 versiyonunda bu durum aşılarak finansal varlıklarda yukarıda açılanan üçlü sınıflandırmaya gidilmiştir.

\section{FINANSAL VARLIKLARDA MUHASEBELEŞTIRME VE ÖLÇME}

Muhasebeleştirme ve ölçmede nakit akış tablosu hariç tahakkuk esasını benimseyen muhasebe standartlarında, ilgili varlığın işletmeye ekonomik yarar sağlaması ve söz konusu kalemin değerinin güvenilir olarak ölçülebilmesi asgari iki şarttır.

\subsection{Muhasebeleştirme Kriteri ve Muhasebeleştirme Yöntemleri}

Bir finansal varlık veya finansal borç, finansal durum tablosunda sadece finansal aracın sözleşmeye bağlı hükümlerine taraf olunması halinde muhasebeleştirilir. Finansal varlıkların normal yoldan alımı veya satımı işlemleri, ticari işlem tarihi muhasebesi ya da teslim tarihi muhasebesinden biri seçilerek uygulanır ve bilanço dışı bırakılır (TFRS 9, m. 3).

Ticari işlem tarihi esas alındığında, işletmenin bir varlığı alma veya satma taahhüdünde bulunduğu tarih esas alınır. Satın alma taahhüdünde elde edilecek varlık ve varlı̆ga ilişkin ödemede bulunma borcunun muhasebeleştirildiği yöntemdir. Bu yöntem tercih edilerek satma taahhüdünde ise satılan varlık bilanço dı̧̧ bırakılır, satıştan doğan kazanç ve kayıplar muhasebeleştirilir ve alıcıya ilişkin bir alacak varlık olarak muhasebeleştirilir.

Teslim tarihi ise bir varlığın işletmeye teslim edildiği veya işletme tarafından teslim edildiği tarihtir. Varlı̆ı̆n işletme tarafindan elde edildiği tarihte muhasebeleştirildiği ya da işletmenin söz konusu varlığı teslim ettiği tarih itibariyle bilanço dışı bırakıldığı, aynı tarih itibariyle elden çıarma kazanç/kayıplarının muhasebeleştirildiği yöntemdir. Teslim tarihi muhasebesinde, işletme teslim aldığı varlıklar gibi ticari işlem tarihi ve teslim tarihi arasındaki dönemde varlığın gerçeğe uygun değerinde meydana gelen değişiklikleri muhasebeleştirir. 


\subsection{Finansal Varlık Yönetim Modelinin Belirlenmesi ve İlk Muhasebeleştirme}

Finansal varlıkların sınıflandırılmasında kilit yönetici tarafından belirlenen işletmenin kullandığ 1 "finansal varlık yönetim modeli” ve sözleşmeye bağlı nakit akış özellikleri dikkate alınarak değerlendirilir. Bu değerlendirmeye göre finansal varlık sınıflandırılır. Finansal varlıklarda ilk muhasebeleştirme gerçeğe uygun değer üzerinden ölçülür (ticari alacaklar hariç). İtfa edilmiş maliyeti üzerinden ölçülen ve G.U.D. farkı diğer kapsamlı gelire yansıtılarak ölçülen finansal varlıkların ilk muhasebeleştirilmesinde edinimle ilgili işlem maliyetleri gerçeğe uygun değere eklenir.

Finansal varlıkla ilgili verilen bedelde başka bir unsuru içerecek şekilde gerçeğe uygun değer belirlenmişse; benzer bir finansal aracın cari faiz oranı kullanılarak iskonto edilmiş bugünkü değeri üzerinden ölçülür. Geriye kalan kredi tutarı, başka tür bir varlık olarak muhasebeleştirilmesi gerekmedikçe, gider veya gelirden indirim olarak kaydedilir.

Ancak bir finansal varlık ilk muhasebeleştirme sırasında gerçeğe uygun değeri ile işlem fiyatı farklı olabilir. İşlem fiyatı, verilen veya alınan bedelin gerçeğe uygun değeridir. Farklılık olması durumunda;

a) Gerçeğe uygun değerin özdeş bir varlığın aktif bir piyasadaki kotasyon fiyatıyla kanıtlanması veya gözlemlenebilir piyasa verileri ile bir değerleme yöntemiyle ölçülmesi esas alınarak G.U.D. üzerinden,

b) İlk muhasebeleştirmedeki gerçeğe uygun değer ile işlem fiyatı arasındaki fark1 ertelemek amacıyla düzeltilmesi sonucunda bulunan tutar üzerinden muhasebeleştirilir. Ertelen bu fark, finansal varlık fiyatlandırılırken dikkat edilecek bir faktör olduğu ölçüde kazanç veya kayıp olarak muhasebeleştirilir.

Finansal varlıklar kapsamında yer alan ticari alacaklar ilk muhasebeleştirmede TFRS 15 'de tanımlanan işlem fiyatı üzerinden ölçülür.

\subsection{Finansal Varlıklarda Dönem Sonu Muhasebeleştirme}

Finansal varlıklar ilk muhasebeleştirmeden sonra başlangıçtaki sınıflandırma kapsamında dönem sonunda ölçülür ve muhasebeleştirilir. IFRS 9'un 2014 versiyonunda “değer düşüklüğ̈̈” önemli bir yaklaşım farklılığı oluşturmaktadır. Değer düşüklüğü "itfa edilmiş maliyeti üzerinden ölçülen" ve "G.U.D. farkı diğer kapsamlı gelire yansıtılarak ölçülen” finansal varlıklara uygulanacaktır.

\subsection{1. İtfa Edilmiş Maliyeti Üzerinden Ölçülen Finansal Varlıklarda Dönem Sonu Değerleme}

İtfa edilmiş edilmiş maliyeti üzerinden ölçülen finansal varlıkla ilgili faiz, temettü, kayıp ve kazançlar, değer düşüklüğü kâr ya da zararda gelir veya gider olarak muhasebeleştirilir. İtfa edilmiş maliyet, finansal varlık veya finansal borcun etkin faiz yöntemiyle hesaplanmış maliyetidir. İlk muhasebeleştirme sırasında ölçülen değerinden 
anapara geri ödemeleri düşüldükten, anılan ilk tutar ile vadedeki tutar arasındaki farkın etkin faiz yöntemi kullanılarak hesaplanan birikmiş itfa payı düşüldükten veya eklendikten ve değer düşüklüğü ya da tahsil edilememe durumuna ilişkin her türlü indirimin yapılmasından sonra geriye kalan tutardır. Etkin faiz yöntemi, finansal aracın itfa edilmiş maliyetlerinin hesaplanması ve ilgili faiz gelir veya giderlerinin ilişkili olduğu döneme dağttılması yöntemidir. Finansal varlığa ilişkin faiz geliri finansal varlı̆̆ın brüt defter değerine etkin faiz oranı uygulanarak hesaplanır.

Gelecekteki Değer = İlk Yatırım Değeri x $(1+\mathrm{i})^{\text {Gün } / 365}$

Yatırım veya borçlanmanın vadesindeki nominal değerden hareket edildiğinde ise bugünkü değeri ortaya çıkacaktır (Aslan, 2011: 103).

Bugünkü Değer $=$ Yatırımın Vadesindeki Değeri $/(1+i)^{\text {Gün /365 }}$

Bugün yapılan 100 TL'lik yatırım ya da borçlanmanın hangi faiz oranında $X$ gün sonra $150 \mathrm{TL}$ olur sorusuna verilen cevap etkin faiz oranıdır. Bu oran yatırımlar için aynı zamanda yatırım anındaki "İç Verim Oranı"dır (Internal Rate of Return - IRR). Eğer bir yatırımın başlangıç ve vadedeki değeri bilinmekte, etkin faiz oranı bilinmemekte ise, etkin faiz oranı yukarıda verilen gelecekteki değer veya bugünkü değer formülleri aracılığı ile hesaplanır. Gelecekteki değer formülü ile elde edilen etkin faiz oranı aslında yatırımın faiz oranıdır. Bugünkü değer formülü sonucunda bulunan etkin faiz oranı ise yatırımın iskonto oranıdır (Aslan, 2011: 104). Etkin faiz oranının hesaplanmasında zorluklarla karşılaşılabilir. Ancak tahmini değerler kullanarak "enterpolasyon yöntemi" ile ya da Excel gibi programlar aracılığıla hesaplanması mümkündür (Ayçiçek, 2011: 65).

\section{Değer Düşüklüğü: Beklenen Kredi Zararları}

TMS 39'da yer alan değer düşüklüğü zararı tutarl; gelecekteki tahmini nakit akışlarının ilk muhasebeleştirme sırasında hesaplanan etkin faiz oranı üzerinden iskonto edilerek hesaplanan bugünkü değeri ile defter değeri arasındaki fark olarak ölçülmekteydi. IFRS 9'un 2014 versiyonunda yer alan önemli değişikliklerden biri de değer düşüklüğü yaklaşımının değiştirilmesidir. Değer düşüklügüu, finansal varlığa ilişkin ömür boyu beklenen kredi zararlarının olasılıklarına göre ağırlıklandırılmış bir tahminidir. İşletmenin almayı beklediği nakit akışları ile sözleşmeye göre yapılması gereken nakit akışları arasındaki fark olan nakit açıklarının bugünkü değeri beklenen kredi zararlarını oluşturmaktadır.

Beklenen kredi zararlarının tahmini için kullanılan azami süre sözleşme süresidir. Değer düşüklüğünün ölçümü, finansal varlığın ilk muhasebeleştirilmesinden değerleme gününe kadar kredi riskinde önemli artş̧lar olan finansal varlığa ilişkin ileriye yönelik olarak makul ve tarafsiz/desteklenebilir tüm bilgiler dikkate alınarak belirlenir. İlk muhasebeleş̧irmeden itibaren kredi riskindeki değişikliğin önemi ilk muhasebeleştirmedeki temerrüt riskine bağlıdır. Beklenen kredi zararlarının değerlendirilmesinde mevcut nitel ve istatistiksel olmayan nicel bilgilerle birlikte istatistiksel modelleri de kapsayan tüm ilgili bilgiler dikkate alınır. Finansal varlığın kredi riskindeki önemli artışlar için finansal varlığın özellikleri ve geçmişte oluşan temerrüt eğilimleri dikkate alınır. Buna göre; 
Finansal varlığa ilişkin kredi riskinin ilk muhasebeleştirmeden itibaren değerleme gününe kadar önemli ölçüde artmıș olması durumunda, dönem sonunda finansal varlığa ait zarar karşılığını ömür boyu beklenen kredi zararlarına eşit bir tutar üzerinden ölçerek gelir tablosunda muhasebeleştirir.

Finansal varlığa ilişkin kredi riskinin ilk muhasebeleştirmeden itibaren değerleme gününe kadar önemli ölçüde artış meydana gelmemesi durumunda finansal varlığa ait zarar karşılığı 12 aylık beklenen kredi zararlarına eşit tutar üzerinden ölçerek gelir tablosunda muhasebeleştirir.

Değer düşüklüğü, finansal varlıklar için bireysel olarak değerlendirilir. Bazı durumlarda bireysel finansal araç bazında ömür boyu beklenen kredi zararlarının ölçümü mümkün olmayabilir. Bu durumda ortak kredi riski özelliklerine göre ( finansal araç türü, kredi riski dereceleri, ilk muhasebeleştirme tarihi, vadeye kalan süre vb.) toplu esasa göre değerlendirme yapılabilmektedir.

Finansal varlığa ilişkin beklenen kredi zararları aşağıdakileri yansıtacak şekilde ölçülür:

a) Olasılıklarla Ağırlıklandırılmış Sonuç: Muhtemel sonuç aralığı değerlendirilerek belirlenen tarafsız ve olasılıklara göre ağırlıklandırılmış tutar belirlenir. $\mathrm{Bu}$ tahmin, kredi zararının meydana gelme olasılığ 1 ile kredi zararı meydana gelmeme olasıllğını yansıtır. 12 aylık olarak belirlenen beklenen kredi zararları finansal varlığın ömrü boyunca beklenen kredi zararlarının bir kısmıdır.

b) Paranın Zaman Değeri: Beklenen kredi zararları gelecekteki bir değer olup, raporlama tarihine etkin faiz oranı ile iskonto edilir.

c) Makul ve Desteklenebilir Bilgi: Geçmiş olaylar, mevcut koşullar ve gelecekteki ekonomik şartlara ilişkin tahminler ışı̆̆ında değerleme gününde aşırı maliyet ya da çabaya katlanılmadan edinilebilen makul ve desteklenebilir bilgi değer düşüklüğünde değerlendirilir. Borçluya özgü etkenler, genel ekonomik şartlar ve bilanço tarihindeki koşullar işletme içi ve dışı faktörler bilgi kaynaklarını oluşturmaktadır. Örneğin, işletmenin geçmiş kredi zararı bilgileri, başka işletmelerin ilgili finansal varlıkla ilgili deneyimleri, işletme dışı derecelendirmeler veri kaynakları arasındadır.

Değer düşüklüğünün ilerleyen dönemlerde azalması ya da sona ermesi durumunda, daha önce kayıtlara alınmış değer düşüklüğü zararı iptal edilir. İptal etme işlemi, doğrudan doğruya veya karşılık hesabının azaltılması suretiyle olur. İptal edilen tutar gelir tablosunda muhasebeleştirilir.

\subsubsection{G.U.D. Farkı Diğer Kapsamlı Gelire Yansıtılarak Ölçülen Finansal Varlıklar}

G.U.D. ile ölçülen bir finansal varlığa ait kazanç ve kayıplar "Diğer Kapsamlı Gelirde" muhasebeleştirilmesi tercih edilmesi durumunda;

a) Sözkonusu finansal varlıkla ilgili kayıp ve kazançlar "Diğer Kapsamlı Gelirde" gösterilir. Akdoğan ve Sevilengül (2007), özkaynağa dayalı finansal araçlara ilişkin gerçeğe 
uygun değer artış ve azalışlarının takibi amacıyla '526 Finansal Varlıklar Değerleme Farkları Hesabı'nı önermişlerdir.

b) TFRS 9'un 2014 versiyonunda "G.U.D. Fark1 Diğer Kapsamlı Gelire Yansitılarak Ölçülen Finansal Varlıklar" için değer düşüklüğü hükümleri uygulanmaktadır. Beklenen kredi zarar karşıllığı, diğer kapsamlı gelirde muhasebeleştirilir ve finansal varlı̆̆ın bilanço değerini azaltmaz. Yukarıda açıklanan değer düşüklüğü ile ilgili hükümler G.U.D. farkı diğer kapsamlı gelire yansıtılarak ölçülen finansal varlıklar için de geçerlidir.

\subsubsection{G.U.D. Farkı Kar / Zarara Aktarlan Finansal Varlıklar}

G.U.D. ile ölçülen bir finansal varlığa ait kazanç ve kayıplar genel olarak "Gelir Tablosu"nda muhasebeleştirilir. Ancak finansal varlık;

a) Finansal riskten korunma ilişkisinin parçası ile "Finansal Korunma Muhasebesi" hükümlerine göre muhasebeleștirilir.

b) Özkaynağa dayalı bir finansal araca yapılan yatırım niteliğindeki finansal varlık ise "Diğer Kapsamlı Gelir"de sunulması tercih edilmişse "Diğer Kapsamlı Gelir Tablosu"nda muhasebeleştirilir.

"G.U.D. Farkı Kar/Zarara Yansttılarak Ölçülen Finansal Varlıklar" için değer düşüklüğü uygulaması bulunmamaktadır.

Teslim tarihi muhasebesi uygulanarak finansal varlıklar muhasebeleştirildiği durumlarda; (TFRS 9, m. 5)

a) İtfa edilmiş maliyetinden ölçülen finansal varlıklara ilişkin işlem tarihi ile teslim tarihi arasında elde edilecek G.U.D. değişiklikleri finansal tablolara yansıtılmaz (değer düşüklüğü zararları hariç),

b) GUD ile ölçülen finansal varlıkların G.U.D.'nde meydana gelen bu tür değişiklikler "Kar veya Zarar Tablosu ve Diğer Kapsamlı Gelir Tablosu"nda muhasebeleştirilir.

Önceki dönemlerde gerçeğe uygun değeri ile muhasebeleştirilen ancak daha sonra G.U.D.'i sıfirın altına düşen finansal varlıklar bir finansal borca dönüşür.

\subsection{Finansal Varlıkların Finansal Durum Tablo Dışında Kalması}

Bir finansal varlığın devredilmesinde ilgili finansal varlı̆̆ın mülkiyetinden kaynaklanan risk ve getirilerin ne ölçüde elde tutulmaya devam edildiği değerlendirilir. Bilanço dışı bırakılan bir finansal varlığın; devir tarihindeki defter değeri ile elde edilen tutar arasındaki fark, "Kar veya Zarar Tablosu"nda muhasebeleștirilir. 
Tablo 2: Finansal Varlıkların Bilanço Dışı Bırakılması

\begin{tabular}{|l|l|l|}
\hline Risk ve Getiriler & Muhasebeleştirme & Sonuç \\
\hline $\begin{array}{l}\text { Önemli ölçüde } \\
\text { devredilmiş ise, }\end{array}$ & $\begin{array}{l}\text { Bilanço dışı } \\
\text { bırakılır. }\end{array}$ & $\begin{array}{l}\text { Defter değeri ile elde edilen tutar } \\
\text { arasındaki fark "Kar veya Zarar } \\
\text { Tablosu"nda raporlanır. }\end{array}$ \\
\hline $\begin{array}{l}\text { Önemli ölçüde elde } \\
\text { tutulmakta ise, ait }\end{array}$ & $\begin{array}{l}\text { İşletmeye } \\
\text { finansal varlıktır. }\end{array}$ & $\begin{array}{l}\text { Finansal varlık } \\
\text { muhasebeleştirilmeye devam edilir. }\end{array}$ \\
\hline $\begin{array}{l}\text { Önemli ölçüde } \\
\text { devredilmemiş ve elde } \\
\text { bulundurulmaya devam } \\
\text { edilmemekte ise, }\end{array}$ & $\begin{array}{l}\text { Kontrol sahibi edilir. } \\
\text { tespit }\end{array}$ & $\begin{array}{l}\text {-İşletme kontrol sahibi değilse, } \\
\text { bilanço dişı bırakılır. } \\
\text {-İşletme kontrol sahibi ise devam } \\
\text { eden ölçüşünde } \\
\text { muhasebeleştirmeye devam edilir. }\end{array}$ \\
\hline
\end{tabular}

\subsection{Finansal Varlıkların Yeniden Sınıflandırılması}

Yönetim modelinin değiştirilmesi durumunda, bu değişiklikten etkilenen tüm finansal varlıklar standardın öngördüğ̈̈ başlangıçtaki sınıflandırma uyarınca yeniden sınıflandırılır.

\subsection{Finansal Varlıklarla İlgili Finansal Tablo Dipnotlarında Açıklanacak Bilgiler}

TFRS 7 finansal araçların finansal durumu ve finansal performansı ile söz konusu finansal araçlara ilişkin maruz kalınan risklerin niteliği, düzeyi ve bu risklerin yönetilme şekli ile ilgili finansal tablolarda kamuoyuna açıklanması gereken bilgileri açıklamaktadır (TFRS 7, m. 1). Söz konusu riskler; kredi riski, yabancı para riski, faiz oranı riski, likidite riski, piyasa riski ve diğer fiyat riski olarak TFRS 7'nin Uygulama Rehberinde açıklanmıştır.

TFRS 7 iki bölüme ayrılabilir. Birinci bölümde, finansal araçların işletmenin finansal durum ve performansına olan etkilerinin anlaşılması amacıyla bilanço, gelir tablosu ve özsermayeye ilişkin açıklamalar yer almaktadır. İkinci bölümde ise finansal araca taraf olmakla maruz kalınan risklerin niteliği ve kapsamına ilişkin açıklamalar yer almaktadır (Şafak, 2007: 1325).

Finansal durum tablosu ve dipnotlarda; "gerçeğe uygun değer farkı 'Kar veya Zarar Tablosu'na aktarılarak ölçülen finansal varlıklar”, "itfa edilmiş maliyeti üzerinden ölçülen finansal varlıklar" ve "gerçeğe uygun değer farkı diğer kapsamlı gelire yansitılarak ölçülen finansal varlıklar” ayrı ayrı sınıflandırılarak açıklanır (TFRS 7, m. 8)

TFRS 7 ile sadece finansal kurum niteliğindeki işletmeler değil, bütün işletmelerin maruz kaldığı risklere ilişkin ölçme ve yönetme bilgileri tek bir standart olarak birleştirilmiştir. Finansal kurum niteliğinde olmayan işletmelerin de söz konusu risklere karş1 daha duyarlı olmaları amaçlanmış ve finansal tablo kullanıcılarının bilgi almaları konusunda daha kapsamlı bir işlev gerçekleştirmiştir (Şafak 2007, 1333). 
Tablo 3: Nitelik ve Kapsamına Göre Finansal Araçlarda Ortaya Çıkan Riskler

\begin{tabular}{|l|l|}
\hline Açıklanacak Bilgiler & Etkilenecek Finansal Araçlar \\
\hline Niteliksel Açıklamalar (nasıl ortaya çıktığı ve özelliği) & $\begin{array}{l}\text { Finansal varlı ve finansal yükümlülüklerine } \\
\text { tamamına her biri için ayrı ayrı }\end{array}$ \\
\hline Niceliksel açıklamalar & $\begin{array}{l}\text { Finansal varlı ve finansal yükümlülüklerine } \\
\text { tamamına her biri için ayrı ayrı }\end{array}$ \\
\hline Kredi riski & $\begin{array}{l}\text { Finansal varlık ve finansal yükümlülükler için (her bir } \\
\text { sinıf için) }\end{array}$ \\
\hline Likidite riski & Finansal yükümlülükler \\
\hline Piyasa riski & Finansal varlık ve finansal yükümlülükler \\
\hline
\end{tabular}

Kaynak: Greuning (2006: 287)

Niteliksel açıklamalar olarak maruz kalınan riskler ve ortaya çıkma şekilleri, risk yönetimindeki hedefler, politikalar, süreçler ile bir önceki dönemden bu cari dönem raporlama tarihine kadar geçen sürede meydana gelen değişiklikleri halka açıklamalıdır. Niceliksel açıklamalarda ise her bir risk türü ile ilgili olarak risklere maruz kalma durumuna ilişkin özet sayısal bilgiler ile dönem sonunda maruz kalınan riskler dönem içinde yaşanan riskleri göstermiyorsa ek bilgileri kamuoyuna açıklamalıdır (Gökçen, Ataman ve Çakıc1, 2011: 81).

\section{FINANSAL VARLIKLARA İLIŞKIN MUHASEBE UYGULAMALARI}

\subsection{Hazine Bonosu Örneği}

İşletme, 01.11.2014 tarihinde nominal fiyatı 60.000 TL olan 90 vadeli hazine bonosunu banka aracılığıyla 56.000 TL'ye satın almıştır.

Etkin Faiz Oranı; $(60.000 / 56.000)^{1 /(90 / 365)}-1=0,32$ olarak hesaplanır.

31.12.2014 tarihinde tahsiline 29 gün kalan hazine bonosunun itfa edilmiş maliyet değeri; $60.000 /(1+0,32)^{29 / 365}=58.708 \mathrm{TL}$ olarak hesaplanır. Kasım ve Aralık aylarına ilişkin hazine bonosu getirisi $58.708-56.000=2.708$ TL olur. Geçmiş olaylar, mevcut şartlar ve gelecekteki ekonomik koşullar bağlamında söz konusu hazine bonolarının değer düşüklüğüne uğramayacağ1 ve beklenen kredi zararlarının oluşmayacağı gözükmektedir.

29.01.2015 tarihinde hazine bonosu nominal değerine ulaşır ve tahsil edilir. Ocak ayında 29 günlük getiri ise $60.000-58.708=1.292$ TL'dir. 


\begin{tabular}{|c|c|c|}
\hline $\begin{array}{r}112 \text { KAMU KESIMI TAH.SEN.BONOLARI } \\
102 \text { BANKALAR }\end{array}$ & 56.000 & 56.000 \\
\hline 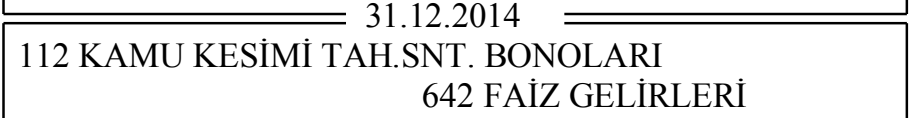 & 2.708 & 2.708 \\
\hline $\begin{array}{ll}102 \text { BANKALAR } & 29.01 .2015 \\
& 112 \text { KAMU KES.T.S.BONOLARI } \\
& \text { 642 FAİZ GELİRLERİ }\end{array}$ & 60.000 & $\begin{array}{r}58.708 \\
1.292\end{array}$ \\
\hline
\end{tabular}

\subsection{Alacak Senedi Örneği}

TFRS 15 kapsamındaki işlemlerden kaynaklanan ticari alacaklara ilişkin zarar karşılıkları her zaman ömür boyu beklenen kredi zararlarına eşit bir tutardan ölçülmektedir.

ABC İşletmesi, ticari alacaklarına ilişkin beklenen kredi zararlarını tahmin etmek amacıyla geçmiş kredi zararı deneyimlerinden faydalanmaktadır. İşletmenin 31.12.2014 tarihi itibariyle ticari alacakları, vadeye kadar olan süre, etkin faiz oranı ve kredi riski oranları aşağıda verilmiştir:

Tablo 4: 31.12.2014 Tarihi İtibariyle Ticari Alacakların Dökümü

\begin{tabular}{|l|l|l|l|l|}
\hline $\begin{array}{l}\text { Ticari } \\
\text { Alacak } \\
\text { Tutarı }\end{array}$ & Vadesi & $\begin{array}{l}\text { Etkin } \\
\text { Faiz } \\
\text { Oranı }\end{array}$ & Vade Durumu & $\begin{array}{l}\text { Kredi Riski } \\
\text { Oranları }\end{array}$ \\
\hline 120.000 & 01.04 .2015 & $\% 12$ & Vadesi geçmemiş & $\% 0,5$ \\
\hline 50.000 & 25.11 .2014 & $\% 10$ & $\begin{array}{l}\text { Vadesinden 30 günden } \\
\text { fazla geçmiş }\end{array}$ & 2 \\
\hline 20.000 & 01.11 .2014 & $\% 12$ & $\begin{array}{l}\text { Vadesi 30-120 gün } \\
\text { aralığında geçmiş } \quad 10\end{array}$ & $\begin{array}{l}\text { Vadesi 120 günden fazla } \\
\text { geçmiş }\end{array}$ \\
\hline 30.000 & 10.04 .2014 & $\% 125$ & \\
\hline
\end{tabular}

Vadesine 3 ay kalmış 120.000 TL'lik alacak senetlerinin itfa edilmiş değeri 120.000 / $(1+0,12)^{3 / 12}=116.618$ TL'dir (Bu alacağın 31.12.2013 tarihindeki peşin değeri $112.500 \mathrm{TL}$ olarak belirlenmiştir). 01.01.2014-31.12.2014 tarihleri arasında ilgili alacağın faiz geliri $116.618-112.500=4.118 \mathrm{TL}$ olarak belirlenir. beklenen kredi zarar1 ise $120.000 \times 0,005=$ 600 TL'dir. Etkin faiz oranı ile gelecekte oluşacak 600 TL'lik kredi zarar karşılığının bugünkü değeri ise; $600 /(1+0,12)^{3 / 12}=583$ TL olarak hesaplanır.

Vadesinden 30 günden fazla geçmiş 50.000 TL'lik alacağın beklenen kredi zararı $50.000 \times 0,02=1.000 \mathrm{TL}$; vadesinden 30-120 gün aralığında geçmiş olan 20.000 TL'lik alacağın beklenen kredi zararı $20.000 \times 0,10=2.000 \mathrm{TL}$ ve vadesinden 120 günden fazla 
geçmiş 30.000 TL'lik ticari alacağın beklenen kredi zararı ise 30.000 x 0,25=7.500 TL olarak belirlenmiştir. Bu durumda toplam beklenen kredi zarar karşıllı̆̆1;

$$
583+1.000+2.000+7.500=11.083 \text { TL'dir. }
$$

\begin{tabular}{|c|c|c|}
\hline $\begin{array}{c}31.12 .2014 \\
122 \text { ALACAK SNT. REESKONTU } \\
642 \text { FAİZ GELİRLERİ }\end{array}$ & $4.118,00$ & $4.118,00$ \\
\hline $\begin{array}{l}659 \text { DİGER OLAĞAN GİD. ZARARLAR } \\
\text { Beklenen Ticari Alacak Kredi Zararları } \\
129 \text { ŞÜPHELİ TİCARİ AL.KRŞ. } \\
\text { Beklenen Ticari Alacak Kredi } \\
\text { Zarar Karşılıkları }\end{array}$ & $11.083,00$ & $11.083,00$ \\
\hline
\end{tabular}

\section{3. İtfa Edilmiş Maliyeti ile Ölçülen Finansal Varlıklarda Değer Düşüklüğü Örneği}

İşletme, 31.12.2014 tarihi itibariyle etkin faiz oranı \% 12 olan 45.000 TL anapara ve 5.000 TL faizi ile birlikte vadesi olan 31.05.2015 tarihinde tahsil edeceği tahvilleri bulunmaktadır. Söz konusu tahvilin mevcut koşullar, borçluya özgü faktörler, ülkenin ekonomik şartları ve diğer bilgiler göz önüne alındığında vadesinde \% 70 oranında tahsil edilebileceği, \% 30 oranında ise kredi zararı meydana gelme olasılığı bulunmaktadır (Beklenen kredi zararı \% 60 olasılıkla 40.000 TL, \% 40 olasılıkla 30.000 TL olarak gerçekleşebileceği tahmin edilmiştir).

İlgili finansal varlığın beklenen kredi zararı; sözleşmeye bağlı nakit akışları ile işletmenin almayı beklediği nakit akışları arasındaki farkın bugünkü değeri olarak hesaplanmaktadır.

Tahvilin vadesinde beklenen olasılıklarla ağırlıklandırılmış değeri şu şekilde hesaplanır:

$$
(50.000 \times 0,70)+[(40.000 \times 0,60 \times 0,30)+(30.000 \times 0,40 \times 0,30)]=45.800 \text { TL olarak }
$$
belirlenir. Söz konusu beklenen kredi zarar1 50.000 - 45.800 = 4.200 TL'dir. Ancak 4.200 TL gelecekteki bir değer olup, etkin faiz oranı ile finansal varlığa ilişkin sözleşmedeki değer ile işletmenin almayı beklediği değer arasındaki nakit açığının bugünkü değeri beklenen kredi zararı olarak muhasebeleştirilmelidir. Buna göre;

Beklenen kredi zararının bugünkü değeri; $4.200 /(1+0,12)^{5 / 12}=4.005$ TL 
654 KARŞILIK GIDERLERI

Finansal Varlık Beklenen Krd.Zararı

119 MENKUL KIYMET DEĞ. DÜŞÜKLÜĞÜ KRŞ.

İtfa Ed.Mal.Ölç.Fin.Var.Ait Beklenen Kredi Zar.Krş.

\subsection{Hisse Senedi Örneği}

İşletme, 10.12.2014 tarihinde Can A.Ş.' ye ait borsada işlem gören hisse senetlerinden 10.000 TL'lik satın almış ve 300 TL işlem maliyetine katlanmıştır. Can A.Ş.'ye ait hisse senetlerinin 31.12.2014 tarihli değeri 9.500 TL olarak belirlenmiştir. 10.02.2015 tarihinde hisse senetleri 10.750 TL’ye satılmıştır.

Söz konusu hisse senetleri "G.U.D. Fark1 Kar veya Zarar Tablosuna Aktarılan Finansal Varlık” olarak sinıflandırılır. Dönem sonu 500 TL'lik G.U.D. fark1 “Kar veya Zarar Tablosu”nda raporlanacaktır. “G.U.D. Farkı Kar veya Zarar Tablosuna Yansıtılarak Ölçülen Finansal Varlık” için değer düşüklüğü hükümlerine tabi değildir.

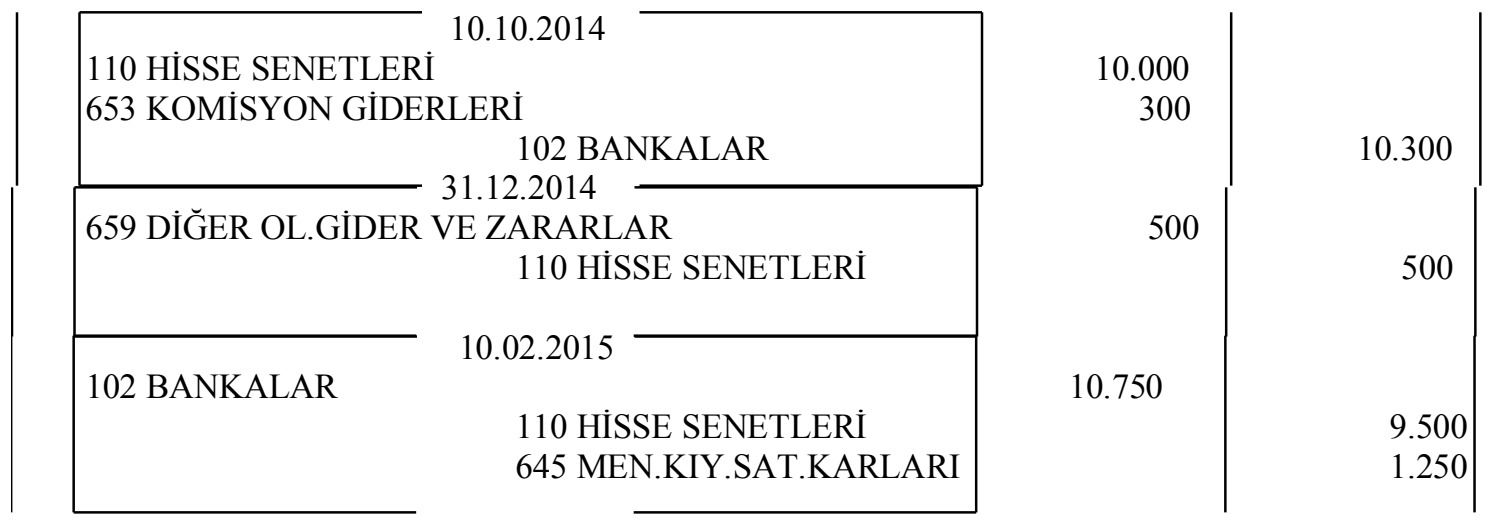

\subsection{G.U.D. ile Ölçülen ve Değerleme Farkı Diğer Kapsamlı Gelirde Raporlanan Finansal Varlık Örneği}

01.01.2014 tarihinde işletmenin 20.000 TL'ye satın aldığ1 9 ay vadeli finansman bonosu satın almıştır. Etkin faiz oranı \% 12 ve 3 aylık dönemlerde faizleri nakit olarak tahsil edilecektir. İşletme, bu finansman bonolarını G.U.D.ile ölçülen ve değerleme farkı diğer kapsamlı gelire yansıtılan finansal varlık olarak sınıflandırmıştır.

31.03.2014 tarihinde ihraç eden firmanın finansman sıkıntısı çektiği ve faiz ödemelerinin \% 60'ını yerine getiremeyeceği, anaparanın da \% 70'ini ödeyebileceği tahmin edilmektedir. 
30.06.2014 tarihinde işletme geçmişteki nakit akışlarının \% 80'ini ödemiştir. Gelecekteki faiz ve anapara ile ilgili nakit akışlarının \%90 oranında gerçekleştirebileceği tahmin edilmiştir.

30.09.2014 tarihinde finansman bonolarına ait faize ilişkin nakit akışlarının tamamı tahsil edilmiş olup, anaparanın ise $\%$ 85'i tahsil edilmiştir.

İşletmenin 31.03.2014 tarihinde gelecekteki nakit akışlarına ilişkin beklenen kredi zararları aşağıdaki tabloda hesaplanmıştır.

Tablo 5: 31.03.2014 Tarihi İtibariyle Değer Düşüklüğü Hesaplaması

\begin{tabular}{|c|c|c|c|c|c|c|}
\hline $\begin{array}{l}\text { Nakit Akış } \\
\text { Tarihi }\end{array}$ & $\begin{array}{l}\text { Sözleşmeye Bağlı } \\
\text { Nakit Akışı }\end{array}$ & $\begin{array}{l}\text { Tahsil } \\
\text { Edilen }\end{array}$ & $\begin{array}{l}\text { İşletmenin } \\
\text { Beklediği } \\
\text { Nakit Akışı }\end{array}$ & $\begin{array}{l}\text { Nakit } \\
\text { Açığ } 1\end{array}$ & $\begin{array}{l}\text { Nakit Açı̆̆ının } \\
\text { Bugünkü Değeri } \\
\text { (Beklenen Kredi } \\
\text { Zararları) }\end{array}$ & $\begin{array}{l}\text { Toplam Değer } \\
\text { Düşüklüğünün } \\
\text { Bugünkü } \\
\text { Değeri }\end{array}$ \\
\hline $\begin{array}{l}\text { 31.03.2014 } \\
\text { tarihli faiz }\end{array}$ & $\begin{array}{l}20.000 \times(0,12)^{3 / 12}= \\
575 \mathrm{TL}\end{array}$ & $\begin{array}{l}230 \\
\mathrm{TL}\end{array}$ & $\begin{array}{l}575 \times 0,40=230 \\
\text { TL }\end{array}$ & $\begin{array}{l}575-230 \\
=345 \mathrm{TL}\end{array}$ & $345 \mathrm{TL}$ & \multirow{4}{*}{$6.675 \mathrm{TL}$} \\
\hline $\begin{array}{l}30.06 .2014 \\
\text { tarihli faiz }\end{array}$ & $\begin{array}{l}20.000 \times(0,12)^{3 / 12}= \\
575 \mathrm{TL}\end{array}$ & - & $\begin{array}{l}575 \times 0,40=230 \\
\text { TL }\end{array}$ & $\begin{array}{l}575-230 \\
=345 \mathrm{TL}\end{array}$ & $\begin{array}{l}345 /(1+0,12)^{3 / 12} \\
=335 \mathrm{TL}\end{array}$ & \\
\hline $\begin{array}{l}\text { 30.09.2014 } \\
\text { tarihli faiz }\end{array}$ & $\begin{array}{l}20.000 x(0,12)^{3 / 12}= \\
575 \mathrm{TL}\end{array}$ & - & $\begin{array}{l}575 \times 0,40=230 \\
\text { TL }\end{array}$ & $\begin{array}{l}575-230 \\
=345 \mathrm{TL}\end{array}$ & $\begin{array}{l}345 /(1+0,12)^{6 / 12} \\
=326 \mathrm{TL}\end{array}$ & \\
\hline $\begin{array}{l}30.09 .2014 \\
\text { tarihli } \\
\text { anapara }\end{array}$ & 20.000 & - & $\begin{array}{l}20.000 \quad x \\
0,70=14.000\end{array}$ & $\begin{array}{l}20.000- \\
14.000= \\
6.000 \mathrm{TL}\end{array}$ & $\begin{array}{l}6.000 /(1+0,12)^{6 / 12} \\
=5.669 \mathrm{TL}\end{array}$ & \\
\hline
\end{tabular}

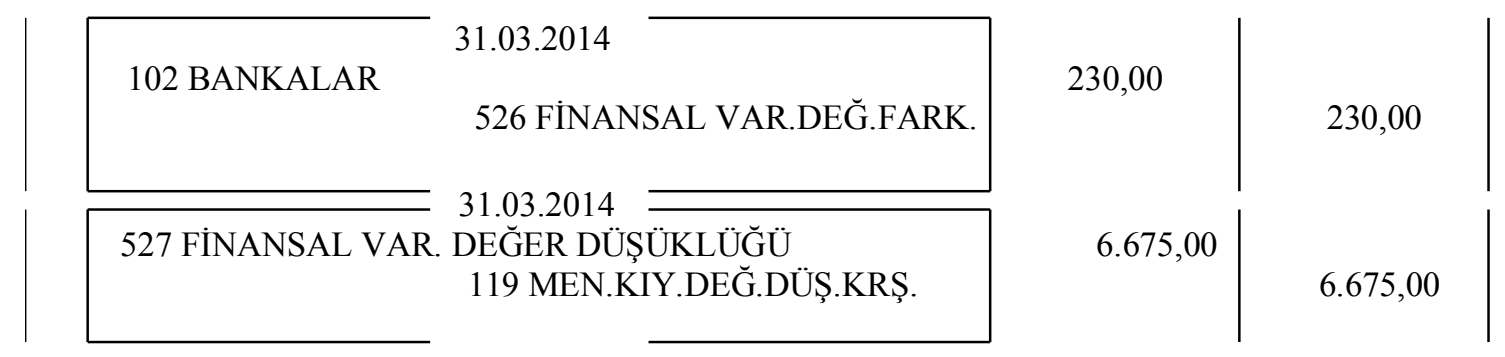

İşletmenin 30.06.2014 tarihinde gelecekteki nakit akışlarına ilişkin beklenen kredi zararları aşağıdaki tabloda hesaplanmıştır. 
Tablo 6: 30.06.2014 Tarihi İtibariyle Değer Düşüklüğü Hesaplaması

\begin{tabular}{|c|c|c|c|c|c|c|}
\hline $\begin{array}{l}\text { Nakit Akış } \\
\text { Tarihi }\end{array}$ & $\begin{array}{l}\text { Sözleşmeye Bağlı } \\
\text { Nakit Akışı }\end{array}$ & $\begin{array}{l}\text { Tahsil Edilen } \\
\text { veya } \\
\text { Beklenen } \\
\text { Nakit Akışı }\end{array}$ & $\begin{array}{l}\text { Beklenen } \\
\text { Kredi Zarar } \\
\text { İptali }\end{array}$ & $\begin{array}{l}\text { Nakit } \\
\text { Açığ }\end{array}$ & $\begin{array}{l}\text { Nakit Açığının } \\
\text { Bugünkü Değeri } \\
\text { (Beklenen Kredi } \\
\text { Zararları) }\end{array}$ & $\begin{array}{l}\text { Toplam Değer } \\
\text { Düşüklüğünün } \\
\text { Bugünkü } \\
\text { Değeri }\end{array}$ \\
\hline $\begin{array}{l}31.03 .2014 \\
\text { tarihli faiz }\end{array}$ & $345 \mathrm{TL}$ & $\begin{array}{l}345 \times 0,80= \\
276 T L\end{array}$ & $\begin{array}{l}345 \times 0,80= \\
276 \mathrm{TL}\end{array}$ & $\begin{array}{l}345-276 \\
=69 \mathrm{TL}\end{array}$ & $69 \mathrm{TL}$ & \multirow{4}{*}{$2.185 \mathrm{TL}$} \\
\hline $\begin{array}{l}30.06 .2014 \\
\text { tarihli faiz }\end{array}$ & $\begin{array}{l}20.000 \times(0,12)^{3 / 12}= \\
575 \mathrm{TL}\end{array}$ & $\begin{array}{l}575 \times 0,80= \\
460 T L\end{array}$ & $\begin{array}{l}335-115= \\
220 \mathrm{TL}\end{array}$ & $\begin{array}{l}575-460 \\
=\quad 115 \\
\text { TL }\end{array}$ & $115 \mathrm{TL}$ & \\
\hline $\begin{array}{l}30.09 .2014 \\
\text { tarihli faiz }\end{array}$ & $\begin{array}{l}20.000 \times(0,12)^{3 / 12}= \\
575 \mathrm{TL}\end{array}$ & $\begin{array}{l}575 \times 0,90= \\
517,50\end{array}$ & $\begin{array}{l}326-56= \\
270 \mathrm{TL}\end{array}$ & $\begin{array}{l}575 \times 0,10 \\
=\quad 57,5 \\
\text { TL }\end{array}$ & $\begin{array}{l}57,5 /(1+0,12)^{3 / 12} \\
=56 \mathrm{TL}\end{array}$ & \\
\hline $\begin{array}{l}30.09 .2014 \\
\text { tarihli } \\
\text { anapara }\end{array}$ & 20.000 & $\begin{array}{l}20.000 \times 0,90= \\
18.000 \mathrm{TL}\end{array}$ & $\begin{array}{l}5669-1945= \\
3.724\end{array}$ & $\begin{array}{l}20.000- \\
18.000= \\
2.000 \mathrm{TL}\end{array}$ & $\begin{array}{l}2.000 /(1+0,12)^{3 / 12} \\
=1.945 \mathrm{TL}\end{array}$ & \\
\hline
\end{tabular}

31.03.2014 tarihinde öngörülen değer düşüklüğü $=6.675 \mathrm{TL}$

30.06.2014 tarihinde öngörülen değer düşüklüğü $=2.185 \mathrm{TL}$

Değer düşüklüğü iptali $=6.675-2.185=4.490 \mathrm{TL}$

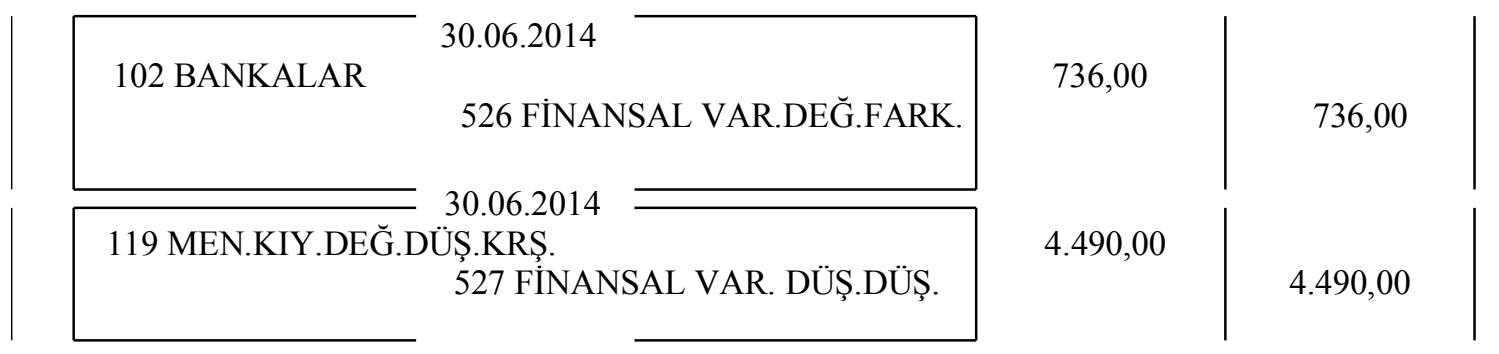

30.09.2014 tarihinde finansman bonolarına ait faize ilişkin nakit akışlarının tamamı tahsil edilmiş olup, anaparanın ise \% 85'i tahsil edilmiştir.

30.06.2014 tarihinde öngörülen değer düşüklüğü = 2.185 TL

30.09.2014 tarihinde öngörülen değer düşüklüğü $=20.000 \times 0,85=17.000$

Sözleşmesi süresi kapsamında toplam değer düşüklüğü $20.000-17.000=3.000 \mathrm{TL}$ olarak 30.09.2014 tarihinde ayrılmalıdır. Buna göre 3.000 - 2.185 = 815 TL karşıllık ayrılarak toplam karşılık tutarı 3.000 TL'ye tamamlanmalıdır. 


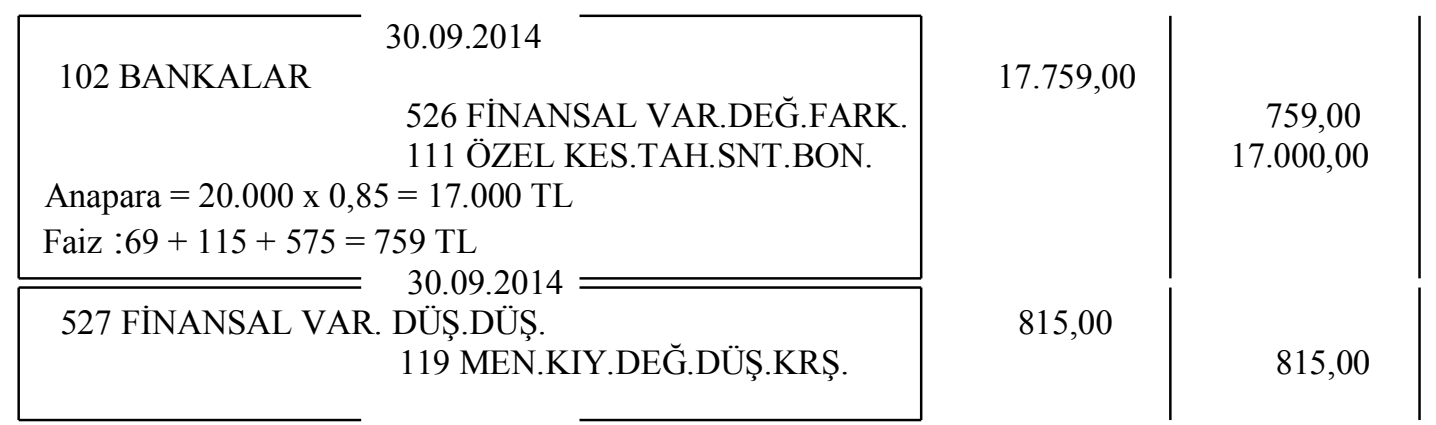

5.6. Etkin Faiz Yöntemi Uygulaması (Mackenzie vd. 2012, 684)

İşletme, 01.01.2011 tarihinde üç yıl vadeli, altı ayda bir faiz ödemeli, \% 12 faiz oranlı nominal fiyatı 10.000 TL olan tahvilleri almıştır. Piyasa faiz oranı \% 10'dur.

Sözkonusu finansal varlığın temerrüt riskinin düşük olduğu ve borçlunun ilgili süre boyunca sözleşmeye bağlı nakit akış yükümlülüklerini yerine getirecek güçlü bir yapısının olduğu diğer işletmelerle olan kredi zarar deneyimlerinden anlaşıldığından beklenen kredi zararlarının oluşmayacağı varsayılmıştır.

Buna göre; altı ayda bir faiz \% 6 ve piyasa faiz oranı altı ay bir $\% 5$ olarak anüite tablosu kullanılarak hesaplamalar yapılmıştır.

10.000 TL'nin her altı ayda bir faizi $10.000 \times(0,12 / 2)=600$ TL hesaplanır.

Yatırım tutarı 10.000 TL'nin \% 5 piyasa faiz oranı ile 6 devre (3 y1l x yılda 2 devre) sonraki değeri anüite bugünkü değer tablosu kullanılarak 10.000 x 0,74622 $=7.462,20$ TL ve 600 TL faizin her devre eklenmesi suretiyle \% 5 faiz oranı ile anüite bugünkü değeri $600 \mathrm{x}$ $5,07569=3.045,41$ TL hesaplanır.

Yatırım net defter değeri başlangıçta 7.472,20 + 3.045,41 = 10.507,61 TL olur.

Tablo 7: Finansal Varlığa İlişkin İtfa Edilmiş Maliyet Tablosu

\begin{tabular}{|l|l|l|l|l|l|}
\hline Tarih & $\begin{array}{l}\text { Nakit Akışı } \\
(\mathrm{a}) \\
(10.000 \quad \mathrm{x} \\
0,06)\end{array}$ & $\begin{array}{l}\text { İskonto Edilmiş } \\
\text { Faiz Geliri } \\
(\mathrm{b}) \\
(\text { Net Defter Değeri } \\
\mathrm{x} 0,05)\end{array}$ & $\begin{array}{l}\text { Kalan Prim } \\
\text { Tutarı } \\
\mathrm{c}=(\mathrm{a}-\mathrm{b})\end{array}$ & $\begin{array}{l}\text { Tahsil Edilmemiş } \\
\text { Toplam Faiz Geliri } \\
(\mathrm{d})=\mathrm{d}-\mathrm{c}\end{array}$ & $\begin{array}{l}\text { Net Defter Değeri } \\
\mathrm{e}=10.000+\mathrm{d}\end{array}$ \\
\hline 01.01 .2011 & & & & 507,61 & $10.507,61$ \\
\hline 01.07 .2011 & 600,00 & 525,38 & 74,62 & 432,99 & $10.432,99$ \\
\hline 01.01 .2012 & 600,00 & 521,65 & 78,35 & 354,64 & $10.354,64$ \\
\hline 01.07 .2012 & 600,00 & 517,73 & 82,27 & 272,37 & $10.272,37$ \\
\hline 01.01 .2013 & 600,00 & 513,62 & 86,38 & 185,99 & $10.185,99$ \\
\hline 01.07 .2013 & 600,00 & 509,30 & 90,70 & 95,29 & $10.095,29$ \\
\hline
\end{tabular}




\begin{tabular}{|l|l|l|l|l|l|}
\hline \hline 01.01 .2014 & 600,00 & 504,71 & 95,29 & -- & $10.000,00$ \\
\hline Toplam & $3.600,00$ & $3.092,39$ & 507,61 & & \\
\hline
\end{tabular}

\begin{tabular}{|c|c|c|c|}
\hline 111 ÖZEL KESIM & $\begin{array}{l}\text { H.SNT.BONOLARI } \\
102 \text { BANKALAR }\end{array}$ & $10.507,61$ & $10.507,61$ \\
\hline 102 BANKALAR & $\begin{array}{l}642 \text { FAİZ GELİRLERİ } \\
111 \text { Ö.K.TAH.SNT.BON. }\end{array}$ & 600,00 & $\begin{array}{r}525,38 \\
74,62\end{array}$ \\
\hline 102 BANKALAR & $\begin{array}{l}\text { 642 FAİZ GELİRLERİ } \\
111 \text { Ö.K.TAH.SNT.BON }\end{array}$ & 600,00 & $\begin{array}{r}521,65 \\
78,35\end{array}$ \\
\hline 102 BANKALAR & $\begin{array}{l}642 \text { FAİZ GELİRLERİ } \\
111 \text { Ö.K.TAH.SNT.BON }\end{array}$ & 600,00 & $\begin{array}{r}517,73 \\
82,27\end{array}$ \\
\hline 102 BANKALAR & $\begin{array}{l}642 \text { FAİZ GELİRLERİ } \\
111 \text { Ö.K.TAH.SNT.BON }\end{array}$ & 600,00 & $\begin{array}{r}513,62 \\
86,38\end{array}$ \\
\hline 102 BANKALAR & $\begin{array}{l}642 \text { FAİZ GELİRLERİ } \\
111 \text { Ö.K.TAH.SNT.BON }\end{array}$ & 600,00 & $\begin{array}{r}509,30 \\
90,70\end{array}$ \\
\hline 102 BANKALAR & $\begin{array}{l}642 \text { FAİZ GELIRLERİ } \\
111 \text { Ö.K.TAH.SNT.BON }\end{array}$ & $10.600,00$ & $\begin{array}{r}504,71 \\
10.095,29\end{array}$ \\
\hline
\end{tabular}

\subsection{Teslim Tarihi Muhasebesi ve Ticari İşlem Tarihi Muhasebesine İlişkin Örnek} (Alexander ve Archer 2010, 16.21)

İşletme, 29.12.2011 tarihinde bir finansal varlığ 1.000 TL’ye satın almıştır. 31.12.2011 tarihinde varlığın gerçeğe uygun değeri 1.002 TL ve teslim tarihi olan 04.01.2012 tarihindeki gerçeğe uygun değeri 1.003 TL'dir. Buna göre teslim tarihi ve ticari işlem tarihindeki bilanço değerleri şu şekilde olacaktır: 
Tablo 8: Teslim Tarihi ve Ticari İşlem Tarihi Hesaplamaları

\begin{tabular}{|c|c|c|c|c|c|c|c|}
\hline \multirow[t]{2}{*}{ Tarih } & \multirow{2}{*}{$\begin{array}{l}\text { Bilanço } \\
\text { Unsuru }\end{array}$} & \multicolumn{2}{|c|}{$\begin{array}{l}\text { G.U.D. Farkı } \\
\text { K/Z'Aktarılan } \\
\text { Finansal } \\
\text { Varlıklar }\end{array}$} & \multicolumn{2}{|c|}{$\begin{array}{ll}\text { İtfa } & \text { Edilmiş } \\
\text { Maliyeti } & \text { Üz.Ölç. } \\
\text { Fin.Var. } & \end{array}$} & \multicolumn{2}{|c|}{$\begin{array}{ll}\text { G.U.D. Farkı Diğer } \\
\text { Kapsamlı } & \text { Gelire } \\
\text { Aktarılan Fin.Var. } & \end{array}$} \\
\hline & & $\begin{array}{l}\text { Teslim } \\
\text { Tarihi }\end{array}$ & $\begin{array}{l}\text { Ticari } \\
\text { İşlem } \\
\text { Tarihi }\end{array}$ & $\begin{array}{l}\text { Teslim } \\
\text { Tarihi }\end{array}$ & $\begin{array}{l}\text { Ticari } \\
\text { İşlem } \\
\text { Tarihi }\end{array}$ & $\begin{array}{l}\text { Teslim } \\
\text { Tarihi }\end{array}$ & $\begin{array}{l}\text { Ticari İşlem } \\
\text { Tarihi }\end{array}$ \\
\hline \multirow{2}{*}{ 29.12.2011 } & $\begin{array}{l}\text { Finansal } \\
\text { Varlıklar }\end{array}$ & - & 1.000 & - & 1.000 & - & 1.000 \\
\hline & $\begin{array}{l}\text { Finansal } \\
\text { Borçlar }\end{array}$ & - & 1000 & - & 1.000 & - & 1.000 \\
\hline \multirow{5}{*}{31.12 .2011} & Alacaklar & 2 & - & - & - & 2 & - \\
\hline & $\begin{array}{l}\text { Finansal } \\
\text { Varlıklar }\end{array}$ & - & 1.002 & & 1.000 & - & 1.002 \\
\hline & $\begin{array}{l}\text { Finansal } \\
\text { Borçlar }\end{array}$ & - & 1.000 & - & 1.000 & - & 1.000 \\
\hline & Özkaynaklar & - & - & - & - & 2 & 2 \\
\hline & $\begin{array}{l}\text { Dağıtılmamış } \\
\text { Karlar }\end{array}$ & 2 & 2 & - & - & - & - \\
\hline \multirow{5}{*}{04.01 .2012} & Alacaklar & 1.003 & - & 1.000 & - & 1.003 & - \\
\hline & $\begin{array}{l}\text { Finansal } \\
\text { Varlıklar }\end{array}$ & - & 1.003 & - & 1.000 & - & 1.003 \\
\hline & $\begin{array}{l}\text { Finansal } \\
\text { Borçlar }\end{array}$ & - & - & - & - & - & - \\
\hline & Özkaynaklar & - & - & - & - & 3 & 3 \\
\hline & $\begin{array}{l}\text { Dağıtılmamış } \\
\text { Karlar }\end{array}$ & 3 & 3 & - & - & - & - \\
\hline
\end{tabular}

\section{SONUÇ}

IASB, finansal araçlar standartlarına yapılan eleştirilere karşılık vermiş olup, 2005 yılında başlattığı finansal araçlar standartlarında uygulanabilir, anlaşılabilir, sade ve fayda/maliyet analizi kapsamında yer alan projeyi IFRS 9 olarak tamamlamaya yaklaşmıştır. 2015 y1lında yürürlüğe girmesi planlanan IFRS 9'un uygulaması, değer düşüklüğü ve finansal riskten korunma muhasebesini de içerecek şekilde 2018 yılına ertelenmiş olup, isteğe bağl1 erken uygulamaya izin verilmiştir. 
IFRS 9'a göre finansal varlıklar “itfa edilmiş maliyeti üzerinden”, “G.U.D. farkı diğer kapsamlı gelire yansitılan" ve "G.U.D. farkı kar/zarara aktarılan” finansal varlıklar olarak gerçeğe uygun değerleri üzerinden ölçülerek ilk muhasebeleştirilmesi yapılır. Edinimde "itfa edilmiş maliyeti üzerinden" ve "G.U.D. farkı diğer kapsamlı gelire yansıtılan” finansal varlıklarla doğrudan ilişkili işlem maliyetleri gerçeğe uygun değere ilave edilir.

Sonraki değerleme dönemlerinde itfa edilmiş maliyeti üzerinden ölçülen finansal varlıklar etkin faiz oranı üzerinden ölçülür ve döneme ilişkin faiz gelirleri gelir tablosunda muhasebeleştirilir. G.U.D. farkı diğer kapsamlı gelire yansıtılan finansal varlıklarda oluşan değerleme farkları diğer kapsamlı gelirde muhasebeleştirilir. G.U.D. farkı kar/zarara aktarılan finansal varlıklarda ise değerleme farkları gelir tablosu ile ilişkilendirilir.

IFRS 9'da yer alan önemli bir farklılık olan değer düşüklüğü, itfa edilmiş maliyeti üzerinden ve G.U.D. farkı diğer kapsamlı gelire yansıtılarak ölçülen finansal varlıklar için geçerlidir. G.U.D. farkı kar/zarara yansıtılan finansal varlıklar değer düşüklüğüne tabi değildir. Değer düşüklüğünde önemli bir yaklaşım farklılığı bulunmaktadır. Değer düşüklüğü; finansal varlığın beklenen kredi zararları için ayrılan zarar karşılığı olup, geleceğe yönelik bir değerlemedir. Finansal varlığın beklenen kredi zarar karşılığı; sözleşmede gerekli olan nakit akışları ile işletmenin almayı beklediği nakit akışları arasındaki nakit açığının bugünkü değeri olarak hesaplanmaktadır. Bu hesaplamada; makul ve desteklenebilir bilgi ışığında gelecekteki olasılıklarla ağırlıklandırılmış sonuç ile paranın zaman değeri dikkate alınır. Değer düşüklüğünde temel hedef, ilk muhasebeleştirmeden itibaren finansal varlık için ileriye dönük makul ve tarafsız bilgiler kapsamında ömür boyu beklenen kredi zararlarının muhasebeleştirilmesidir.

IFRS 9'da yapılan son değişiklerle birlikte sınıflandırma/ölçme, değer düşüklüğü ve finansal riskten korunma muhasebesi bir bütünlüğe yakınlaşmıştır. Finansal varlıkların gelecekte beklenen nakit akışlarını ölçmek ülkelerin finansal piyasalardaki gelişmişlik düzeyi ile doğru orantılıdır. Gelecekteki belirsizlikleri ölçmek ve değerlemek gelişmekte olan ülkeler için zor olduğundan değer düşüklüğü ile ilgili makul, tarafsız ve desteklenebilir ileriye dönük bilginin aşırı maliyet ve çabaya katlanılmadan elde edilmesinde bazı güçlüklerle karşılaşılması muhtemeldir.

\section{KAYNAKLAR}

Akdoğan, Nalan - Sevilengül, Orhan (2007), Tekdüzen Muhasebe Sistemi Uygulaması, Gazi Kitabevi, 12. Bask1, Ankara.

Alexander, David - Archer, Simon (2010), International Accounting/Financial Reporting Standards Guide, CCH Learning Center, Chicago.

Aslan, Ümmühan (2011), "Bankalarda 'Vadeye Kadar Elde Tutulacak Menkul Kiymet' İşlemleri ve Etkin Faiz Yöntemi”, Muhasebe ve Finansman Dergisi, Ekim, s. 95-120. 
Ayçiçek, Fahri (2011), "TMS 39 Çerçevesinde Bir Finansal Araç Olarak Tahviller", Muhasebe ve Finansman Dergisi, Nisan, s. 59-76.

Bal, Emine Çına (2013), "Türkiye Finansal Raporlama Standardı - 9 Finansal Araçlar Standardına Göre Finansal Araçların Sınıflandırılması ve Uygulama Örnekleri”, İşletme Araştırmaları Dergisi, s. 47-63.

Demir, Volkan (2008), "Finansal Araçlar: Sunum, Muhasebeleştirme ve Ölçme, Açıklamalar", Seçilmiş Türkiye Finansal Raporlama Standartları, İSMMMO Yayını No: 99, 1.Bask1, İstanbul, s. 97-116.

Gökçen, Gürbüz - Ataman, Başak - Çakıc1, Cemal (2011), Türkiye Finansal Raporlama Standartları Uygulamaları, Türkmen Kitabevi, İstanbul.

Greuning, Hennie Van (2006), International Financial Reporting Standards - A Practical Guide", 4th Edition, The World Bank, Washington.

Haftacı, Vasfi - Pehlivanlı, Davut (2007), "UMS 39 ve Uygulamada Karşılaşılan Sorunlar", Kocaeli Üniv. Sosyal Bilimler Enstitüsü Dergisi, s. 139-151.

İşseveroğlu, Gülsün (2014), "TMS 39 Kapsamında Finansal Varlıkların Sınıflandırılması ve Değerlemesi: Borsa İstanbul 100 Endeksindeki Şirketlerin Uygulamaları", Uluslararası Yönetim İktisat ve İşletme Dergisi, Cilt 10, Sayı 21, s. 87-106.

Kaval, Hasan (2008), "Finansal Araçlarda Sunum, Değerleme ve Açıklamalar", Türkiye Muhasebe - Finansal Raporlama Standartları, Gazi Kitabevi, 2. Bask1, Ankara, s. 469, 522.

Mackenzie, Bruce - Coetsee, Danie - Njikizana, Tapiwa - Chamboko, Raymond - Colyvas, Blaise - Hanekom, Brandon (2012), Interpretatiton and Application of International Financial Reporting Stardards, John Wiley \& Sons, New Jersey.

Mısırlığlu, İsmail Ufuk (2008), "Türkiye Muhasebe Standartlarına Göre Finansal Araçların Muhasebeleştirilmesi”, Mali Çözüm Dergisi, Sayı: 86, s. 65-82.

Şafak, Bekir Sttkı (2007), "TFRS 7 Finansal Araçlar: Açıklamalar", Türkiye Muhasebe Standartları Uygulaması", Maliye ve Hukuk Yayınları, Ankara, s. 1323-1335. 